\title{
Compiling a jury in Russia in the context of digitalization
}

\author{
Sergey A. Pashin, Nikita V. Bushtets* \\ National Research University Higher School of Economics (NRU HSE), \\ Moscow, Russian Federation, \\ *n.bushtets@mail.ru
}

\begin{abstract}
The purpose of this study is to conduct a comprehensive analysis of the legislation governing social relations that develop in the process of compiling a jury when considering criminal cases with a jury trial. The relevance of the research topic is determined by the expansion of the jurors' competence from June 1, 2018. Currently, one of the main reasons for revocation of court sentences passed with the participation of a jury is violations committed during formation of a jury. In this regard, the authors highlight the main procedural and organizational shortcomings of this process and make relevant suggestions: a) to improve the legislation governing the procedure for compiling a jury; b) to compile general and reserve lists based on information included in the Unified Federal Information Register; c) to perform video recording of the process [screen broadcasting] of a random selection of citizens from the general and reserve lists by a court staff member when compiling a preliminary list of jurors; d) to stipulate the right of citizens to defer the obligation to appear in court as a candidate for jurors to a later date; e) to apply new forms of sending invitations to appear in court to potential jurors.
\end{abstract}

Key words: trial by jury, expanding the competence of jurors, defense in court of jurors, organization of the court's activities, digitalization

Conflict of interest. The authors declare that there is no conflict of interest.

The participation of the authors: Pashin S.A. - concept of the article, general overview, introduction; Bushtets N.V. - analysis and scientific development of materials, conclusion, copywriting.

Article received 22nd October 2020

Article accepted 15th April 2021

\section{For citation:}

Pashin, S.A., Bushtets, N.V. (2021) Compiling a jury in Russia in the context of digitalization. RUDN Journal of Law. 25 (2), 620 -633. DOI: 10.22363/2313-2337-2021-25-2$620-633$

(C) Pashin S.A., Bushtets N.V., 2021

This work is licensed under a Creative Commons Attribution 4.0 International License https://creativecommons.org/licenses/by/4.0 


\title{
Формирование коллегии присяжных заседателей в условиях цифровизации
}

\author{
С.А. Пашин, Н.В. Буштец* \\ Национальный исследовательский университет «Высшая школа экономики», \\ 2. Москва, Российская Федеращия, \\ *n.bushtets@mail.ru
}

\begin{abstract}
Аннотация. Цель исследования - провести комплексный анализ законодательства, регулирующего общественные отношения, которые складываются в процессе формирования состава присяжных при рассмотрении уголовных дел с участием присяжных. Актуальность темы исследования обусловлена расширением компетенции присяжных заседателей с 1 июня 2018 г. В настоящее время одной из основных причин отмены приговоров суда, вынесенных с участием присяжных заседателей, являются нарушения, допущенные при формировании коллегии присяжных. В связи с этим авторы выделяют основные процедурные и организационные недостатки этого процесса и вносят соответствующие предложения: а) усовершенствовать законодательство, регулирующее порядок формирования жюри; б) составлять общий и резервный списки на основании сведений, включенных в Единый федеральный реестр информации; в) производить видеозапись процесса [экранной трансляции] произвольного отбора граждан из общего и резервного списков сотрудником суда при составлении предварительного списка присяжных заседателей; г) закрепить право граждан отложить обязанность явки в суд в качестве кандидата в присяжные заседатели на более поздний срок; д) применять новые формы направления приглашений в суд к потенциальным присяжным заседателям.
\end{abstract}

Ключевые слова: суд присяжных, расширение компетенции присяжных заседателей, защита в суде присяжных, организация деятельности суда, цифровизация

Конфликт интересов. Авторы заявляют об отсутствии конфликта интересов.

Информация о вкладе авторов: Пашин С.А. - концепция статьи, общий обзор, введение; Буштец Н.В. - анализ и научная разработка материалов, заключение, копирайтинг.

Дата поступления в редакичию: 22 октября 2020 г.

Дата принятия к печати: 15 января 2021 г.

\section{Для цитирования:}

Pashin S.A., Bushtets N.V. Compiling a jury in Russia in the context of digitalization // RUDN Journal of Law. 2021. T. 25. № 2. C. 620 - 633. DOI: 10.22363/2313-2337-2021-25-2-620-633

\section{Introduction}

Expanding the competence of the institute of a jury trial and analysis of its work contribute to the current interest of the topic; of special interest are those of its components that affect the most important aspects of this institute's activity. Compiling a list of jurors is a very important stage in the work of a trial by jury, since without putting together the list it is impossible to ensure a legality of the jury composition and comply with a precondition for a fair trial (Sheremetyev, 2020:117-131). 
Compiling the lists of jurors should be considered as a separate organizational element, consisting of a number of procedures designed to facilitate the administration of justice for criminal cases considered by a jury trial.

The shortcomings of this process often lead to the situation when individuals having no right to be jurors get to the jury. The composition of the jury may violate the norms, which subsequently entails the revocation of the sentence ${ }^{1}$.In this case, the accused and the victim involved in the legal proceedings are interrogated during the judicial investigation again, thus experiencing a psycho-traumatic situation for the second time. At the same time, the judicial and budgetary systems bear an additional burden due to the procedural violation.

According to the Judicial Department of the Supreme Court of the Russian Federation (hereinafter referred to as the Judicial Department) in 2019, in Russia, a quarter of all sentences $(22.9 \%$ ) passed by a court of jurors were revoked on appeal due to a significant violation of the criminal procedure law $^{2}$. This includes a number of uncommon cases with invalid trials with a jury.

This trend can also be traced at the present time. Thus, in the first half of 2020, oblast courts and courts equivalent to them revoked $19.5 \%$ of convictions and $87.8 \%$ of acquittals passed by district courts with participation of jurors (Hodzhaeva, 2020).

The previously indicated problem was the subject of discussion in the scientific literature. In particular, E.V. Avdeeva and A.N. Aksenov noted that the most frequent reason for revocation of sentences passed by the courts of jurors was violation associated with the selection and empanelment of jurors. (Avdeeva \& Aksenov, 2019:13-18).

These circumstances confirm the authors' opinion on the need to identify and analyze the reasons contributing to compilation of juries subsequently recognized as invalid and develop optimal proposals for improving legal regulation of relations in this area.

\section{Normative Legal Regulation}

The overall organization of the activities of federal courts of general jurisdiction is carried out by the Judicial Department and its territorial bodies in the constituent entities of the Russian Federation. Preparation for the consideration of criminal cases by the trials with jury is performed by the apparatus of the relevant court based on the standard procedure and at the expense of the federal budget. In accordance with subparagraphs 3.2 and 4.3.2 of the Regulations on the Apparatus of the Federal Court of General Jurisdiction ${ }^{3}$, the task of the court is to assist judges in attracting citizens to the administration of justice. The main areas of activity of the Department for provision

\footnotetext{
${ }^{1}$ Clause 14 of the Resolution of the Plenum of the Supreme Court of the Russian Federation No 23 of November 22, 2005 On the Application by the Courts of the Norms of the Criminal Procedure Code of the Russian Federation Governing Legal Proceedings with the Participation of Jurors. Legal Reference Database ConsultantPlus.

${ }^{2}$ Official website of the Judicial Department of the Supreme Court of the Russian Federation. Available at: http://www.cdep.ru/index.php?id=79\&item=5258 [Accessed 30 ${ }^{\text {th }}$ September 2020].

${ }^{3}$ Approved by the Order of the Judicial Department No 238 of December 21, 2012. Legal Reference Database ConsultantPlus.
} 
of legal proceedings of criminal cases are the organization and conduct of proceedings on criminal cases with participation of jurors.

The most comprehensive understanding of the organization of work with jurors, including the procedure for compilation of general and reserve lists of jurors, can be obtained from the Criminal Procedure Code of the Russian Federation (hereinafter referred to as the Criminal Procedure Code), Federal Law No 113-FZ of August 20, 2004 On Jurors of Federal Courts of General Jurisdiction of the Russian Federation (hereinafter referred to as the Federal Law on Jurors), Resolutions of the Plenum of the Supreme Court of the Russian Federation No 5 of February 13, 2018 On the Application by the Courts of Certain Provisions of the Federal Law On Jurors of Federal Courts of General Jurisdiction of the Russian Federation, Instructions on Judicial Proceedings in Oblast Courts (and courts equivalent to them) and district courts ${ }^{4}$.

\section{Compiling of General and Reserve Lists of Jurors}

The supreme executive body of the state power of the constituent territories of the Russian Federation compiles general and reserve lists of candidates for jurors. Compiling of such lists takes place on the basis of information provided by the executive and administrative bodies of municipalities ${ }^{5}$. Future jurors are identified by random selection from GAS "Vybory" [the State Automatic System "Elections"] database. Monitoring of the approved lists is carried out annually (or more often, upon separate request by the chief judge of the court) by the bodies that compiled them.

Following the expansion of competences of jury trials in district courts, the procedure for compiling lists of candidates for jurors has undergone changes; now the lists are sent to district courts and procedure for their approval is clarified. In order to ensure the correct and uniform application of the new norms by the courts, the Plenum of the Supreme Court of the Russian Federation (hereinafter referred to as the Supreme Court) provided appropriate explanations. However, unfortunately, in its explanations the Supreme Court ignored the issues of monitoring information included in the lists by the authorized bodies ${ }^{6}$.

In our opinion, one of the reasons for the inclusion of individuals who cannot be jurors is, first of all, the improper compilation by the authorized bodies of the general and reserve lists from which a staff member of the court selects candidates for jurors.

The problem noted by us is widely discussed by the scholars. For example, V.P. Lukin (Lukin, 2004:241), M.A. Dzhabrailov (Dzhabrailov, 2012:41-45), O.N. Tisen (2008), N.P. Vedishhev (Vedishhev, 2011:19—28) referred to low quality of the lists compiled by the executive authorities and pointed out that the authorized bodies, in contradiction with the legislative provisions, did not update or correct them.

\footnotetext{
${ }^{4}$ Approved by Orders of the Judicial Department of the Supreme Court of the Russian Federation No 36 of April 29, 2003 (as amended on October 21, 2019) and No 161 of December 15, 2004 (as amended on October 28, 2019).

${ }^{5}$ Part 7 of Article 5 of the Federal Law No 113-FZ of 20.08.2004 (as amended on 01.10.2019) On Jurors of the Federal Courts of General Jurisdiction of the Russian Federation. Legal Reference Database Consultant Plus.

${ }^{6}$ Resolution of the Plenum of the Supreme Court of the Russian Federation No 5 of 13.02.2018 On the Application by the Courts of Certain Provisions of the Federal Law On Jurors of the Federal Courts of General Jurisdiction of the Russian Federation. Legal Reference Database ConsultantPlus.
} 
As noted above, the inclusion of individuals having no right to serve as jurors in the preliminary list of candidates and their subsequent inclusion in the jury leads to revocation of the sentence and occurrence of other adverse consequences for both the parties and the state ${ }^{7}$.

In order to minimize the above risk, we believe it necessary to analyze the mechanism for implementing Articles 5 and 7 of the Federal Law on Jurors, which regulate the procedure for compiling lists of candidates for jurors and suggest new organizational and legal approaches to the solution of the indicated problem, taking into account the revision of the current legislation and digital technologies available today.

The first factor to pay attention to is the database from which the selection of candidates for jurors is carried out. Currently, the selection is performed by random sampling, using GAS "Vybory" system on the basis of personal data about voters contained in this information resource. This database contains information about individuals with active suffrage. However, the requirements for jury candidates differ significantly from the requirements for citizens with active suffrage. For example, citizens of the Russian Federation have the right to vote from the age of 18, while a citizen can be a juror from the age of 25. N.P. Vedishchev points out that GAS "Vybory" database includes information about individuals with limited legal capacity, without indicating this legal circumstance (Vedishchev, 2011:19-28). For this reason, O.N. Tisen proposes to create a unified database of citizens with limited legal capacity and incapacitated that would be accessible to bodies performing screening of candidates for jury (Tisen, 2008:7-9).

We should agree with the opinion of T.A. Vladykina, indicating that from the proposal of O.N. Tisen it is not entirely clear who would compile and update such a database (Vladykina, 2018: 212). The question of processing the personal data of citizens included in this database also remains open.

In addition, we draw attention to the fact that the maintenance of a separate information system would require allocation of significant financial resources, while functionality of this database is limited to just one task: assistance in compiling the lists of jurors. This leads to the idea of implementing this function on the basis of existing information systems, which could reduce the financial and time resources needed to create a new information system, allowing for data processing on one platform.

In our opinion, the Unified Federal Information Register (created in 2020) containing information about the population of the Russian Federation (hereinafter referred to as the Register $)^{8}$, could serve as a database for compiling the lists of jurors, since it includes much more information about the population than GAS "Vybory".

Thus, for the purpose of a random selection of candidates to jurors from the Register, it would only be necessary to develop an appropriate application algorithm.

\footnotetext{
${ }^{7}$ Clause 14 of the Resolution of the Plenum of the Supreme Court of the Russian Federation No 23 of November 22, 2005 (as amended on May 15, 2018) On the Application by Courts of the Norms of the Criminal Procedure Code of the Russian Federation Regulating Legal Proceedings with the Participation of Jurors. Bulletin of the Supreme Court of the Russian Federation, No 1. 2006.

${ }^{8}$ Federal Law No 168-FZ of 08.06.2020 On the Unified Federal Information Register Containing Information on the Population of the Russian Federation. SZ RF, 15.06.2020, No 24, Art. 3742.
} 
However, this does not exclude the responsibility of the executive authorities of the Russian regions and local self-government bodies to conduct an additional verification in order to exclude individuals having no right to be a juror from the lists right before the transfer of the corresponding lists to the courts.

\section{Compiling a Preliminary List of Jurors}

The procedure for compiling a preliminary list of jurors directly by employees of the court apparatus on the basis of the general and reserve lists is regulated by article 326 of the Criminal Procedure Code of the Russian Federation.

This norm establishes four stages of work, each of which is of an important organizational and legal significance:

- selection by the secretary (or judge's assistant) of candidates for jurors from the general and reserve lists,

- verification by the secretary (or judge's assistant) of the circumstances that prevent an individual from participating as a juror in a criminal case,

- compiling a preliminary list of candidate jurors,

— sending notices to the candidate jurors.

\section{Selection of candidates for jury service from the general and reserve lists}

The preliminary list of jurors is initiated by the judge presiding at the trial after the issuance of the order regarding the court session. A copy of this order shall be sent to the court clerk office for selection of candidates for jurors from the general and reserve lists based on random sampling by the authorized member of the court staff 9 .

The process for jurors' selection is often justifiably criticized in the scientific literature. So, I.L. Petrukhin, among the disadvantages of this process quite fairly noted that the law determined neither the procedure for compiling a preliminary list of jurors nor who and in what capacity should be present in this process. In order to avoid abuse and bias, he suggested stipulating a provision for participation of the parties or at least the public prosecutor and defense attorney during selection and empanelment of jurors for the trial (Petruhin, 2003:192). Although, the participation of the parties in compiling a preliminary list of jurors could slightly delay the process of considering a criminal case, at the same time, the current situation cannot be ignored, since it is a question of securing the right of the accused to a fair trial within a reasonable time.

The actual lack of transparency in the compilation of the preliminary list of jurors leads to the inclusion of individuals who are not eligible to serve as jurors. These are dubious cases impossible with fair use of a computer selection system that assumes a random number generator, for example, appearance on the list of candidates in alphabetical order or residents of one neighborhood. Lawyers working in courts of jurors have repeatedly expressed suspicion about database manipulation, when certain social groups, whose participation in the processes is difficult to secure and requires additional costs (in particular, farmers) are excluded from the selection in advance. The

\footnotetext{
${ }^{9}$ Part 1 of Article 326 of the Criminal Procedure Code of the Russian Federation No 174-FZ of 18.12.2001 (as amended on 31.07.2020). SZ RF, 24.12.2001, No 52, Art. 4921.
} 
practice of preliminary consultation with the potential jurors about the time convenient for their appearance in court (they are invited in accordance with their preferences), is also impossible with a full-fledged random selection of candidates from the general list. The latter approach does not seem to be absolutely inappropriate when the general list of candidates includes several thousand names, provided that the candidates are selected not for a specific trial, but for a certain period of time. But in any case, the procedure for coordinating working time with potential jurors should be legalized to avoid doubts about objectivity/impartiality of the jury, honesty of judges and court staff.

A.V. Gabov, N.M. Khromova argue that the problem of the procedure for compiling a jury rests in the implementation of the entire complex of procedural actions that ensure legality of the future composition of the jury not by a judge or in the form of a trial, but by the court secretary or the judge's assistant, outside of the framework of the judicial procedure, and when selection of candidates is performed by using a computer program (Gabov \& Hromova, 2016:4-11).

It should be noted that T.A. Vladykina proposes to supplement Part 1 of Article 326 of the Criminal Procedure Code with a provision on keeping the protocol of a random selection of candidates for jurors attached to the criminal case files (Vladykina, 2018:208).

However, this does not exclude the possibility of abuse during compiling the preliminary list of jurors. The question is what information should be included in the specified protocol, who keeps it, and whether the parties are present.

It is advisable to consider amending Article 326 of the Criminal Procedure Code with a provision for a video recording of the process of compiling the list of jurors [screen broadcasting] and adding it to the criminal case file. This procedure will allow the parties to freely familiarize themselves with the video and, if any violations are identified, appeal to a higher court. Adoption of this proposal would reduce the risks of unlawful actions by officials, without complicating the trial and delaying the hearing of a criminal case. At the same time, in case of implementation of the proposed changes, the financial costs will be minimal, since the function of recording the screen broadcasting is often provided in the computer's operating system by default.

\section{Verification of the circumstances that prevent an individual from participating as a juror in a criminal case}

In accordance with Part 2 of Article 326 of the Criminal Procedure Code, the secretary of the court session or the judge's assistant verifies whether there are circumstances stipulated by the federal law that prevent an individual from participating as a juror in a criminal case.

At the same time, neither the Instruction on Judicial Proceedings nor other regulations, specify the mechanism for verification of the reliability of the information provided by the candidates for jurors by the court staff (Tarasov, 2016:15-17).

As noted by V.N. Tarasov, there are cases when candidates withhold information about their short-term work at law enforcement agencies, their previous convictions, and / or cases of administrative responsibility (Tarasov, 2016:15-19). 
The interviewing of the candidates for jurors by the presiding judge to reveal circumstances preventing from performing the duties ${ }^{10}$ is not a guarantee that juror candidates have provided reliable information either.

As noted by A.L. Osipov, the candidates for jurors do not bear any other than procedural legal responsibility for the reliability of their answers. At the same time, the inaccuracy of the information provided by them becomes known after the sentence is passed, that is, at the stage when the jurors can no longer be brought to procedural responsibility (Osipov, 2016:29-32).

Moreover, there are reasons to believe that in a number of cases, individuals not meeting the requirements for jurors are deliberately included in the jury. This creates future opportunities for the parties to get the unwanted, in their opinion, sentence and verdict revoked.

In the scientific literature, there is a discussion about how a court staff member should verify the reliability of the information provided by the candidates for jurors (Fadeeva, 2019:46 - 49) in the absence of a relevant mechanism stipulated by regulations.

It should be taken into account that in this case we are talking about disclosing of the confidential information that constitutes privacy of a citizen, protected by law. The procedure and conditions for disclosing information, dissemination of which limits the rights and freedoms of an individual, should be exclusively stipulated at the level of the federal law ${ }^{11}$ level (Part 3 of Article 55 of the Constitution of the Russian Federation). This is confirmed by provision of Part 1 of Article 152.2 of the Civil Code of the Russian Federation according to which collection, storage, distribution and use of any information about the private life of a citizen is not allowed without his/her consent, unless it is otherwise directly stipulated by law.

In addition, in accordance with Part 1 of Article 10 of the Federal Law on Jurors, citizens can be called up to serve as jurors once a year. Meanwhile, the current legislation does not establish any procedure for monitoring the implementation of this provision $^{12}$.

In this regard, it is very important not only to stipulate a proper form of control, but also to stipulate the responsibility of officials for failure to comply with the requirements for calling citizens to justice more often than once a year. The issue of the procedural consequences of attracting to jury service "regular" jurors should be discussed separately.

\footnotetext{
${ }^{10}$ Resolutions of the Plenum of the Supreme Court of the Russian Federation No 23 of November 22, 2005 On the Application by the Courts of the Norms of the Criminal Procedure Code of the Russian Federation Governing Legal Proceedings with the Participation of Jurors. Legal Reference Database ConsultantPlus.

${ }^{11}$ Human and civil rights and freedoms may be limited by the federal law only to the extent necessary for protection of the foundations of the constitutional order, morality, health, rights and legitimate interests of others, to ensure the country's defense and security of the state.

${ }^{12}$ In the past, the absence of such control significantly distorted functioning of the institution of people's assessors. We are talking about those cases when people's assessors actually became staff members of the corresponding court, working for years with the same judge. As a result, the idea of this institution of people's participation in administering justice was lost, and the assessors naturally received the nickname "those who are nodding". The requirement of the law to involve people's assessors to the work at court for no more than two weeks was simply ignored. See: (Bushtets, 2019).
} 
As one can see, many issues concerning jurors are not covered in a sufficient detail by the federal legislation. This is proved by the fact of issuance of various "methodological recommendations for working with juries" $" 13$ by the courts to make up for the imperfection of the regulatory framework. The content of these recommendations shows that a uniform approach to regulating the same issues related to work with jurors has not been developed so far, which entails a contradictory law enforcement practice of administration of trials at different courts.

In this regard, it seems relevant to refer to the opinion of the Constitutional Court of the Russian Federation, established in the Resolution No 6-P of January 21, 2019, according to which the principle of legal equality (Part 1 of Article 19 of the Russian Constitution) necessitates formal certainty, accuracy, clarity, unambiguousness of legal norms and their consistency in the system of existing legal regulation, since legal equality can be ensured only under the condition of a uniform understanding and interpretation of the legal norm. Legal provisions that do not meet the specified criteria entail a contradictory law enforcement practice, create a possibility of an ambiguous interpretation and arbitrary application, and thus lead to the violation of citizens' rights to judicial protection ${ }^{14}$.

Thus, the unresolved issues of administering jury trials should be resolved at the level of federal laws and by-laws, providing a uniform approach to regulating legal relationship in this area.

Based on the above, we believe it necessary to amend Part 2 of Article 326 of the Criminal Procedure Code in order to clarify the procedure and conditions for providing a secretary of the court or judge's assistant with the information about juror candidates that may prevent them from participating in the criminal case as provided for by the federal law. At the same time, it should be taken into account, that criminal jury trial must begin no later than 30 days from the date of the judge's decision. It should also be noted that the proposed innovations may entail the need to introduce relevant amendments to Part 1 of Article 12 of the Federal Law On Police in terms of obliging the police to provide information on the presence (absence) of a criminal record and/or the fact of criminal prosecution at the request of the court staff member.

In fact, on June 23, 2020, the State Duma of the Federal Assembly of the Russian Federation considered and adopted in the first reading the draft Federal Law No 706820-7 On Amendments to Articles 12 and 17 of the Federal Law On the Police obliging the police to provide information on whether an individual has an outstanding or unexpunged conviction, as well as information on individuals suspected and accused of committing a crime to the supreme executive body of the state power of the Russian Federation constituent and the executive and administrative body of municipality to

\footnotetext{
${ }^{13}$ For example: Methodological Recommendations on the Organization of Court Proceeding on Criminal Cases with Participation of Jurors, approved by the Resolution of the Presidium of the Yamalo-Nenets Autonomous District on May 17, 2017; Methodological Recommendations for Consideration of Criminal Cases with Participation of Jurors adopted by the Supreme Court of the Republic of Tatarstan.

${ }^{14}$ Resolution of the Constitutional Court of the Russian Federation No 6-P of 21.01.2019, On the Case of Verification of Constitutionality of Article 112 of the Code of Administrative Procedure of the Russian Federation in Connection with the Complaint of Citizens N.A. Balanyuk, N.V. Lavrentieva, I.V. Popov and V.A. Chernyshev. Bulletin of the Constitutional Court of the Russian Federation, No. 2, 2019.
} 
exercise the assigned authority of compiling general and reserve lists of candidates for jurors $^{15}$.

At the same time, the draft law does not provide for possibility of a prompt receipt of the specified information by a court staff member who directly selects candidate jurors from the general and reserve lists held at court and verifies them for circumstances that may prevent an individual from participating in a criminal case as provided for by the federal law. Neither the draft law takes into account the fact that the status of information on a citizen's criminal record, as well as information on individuals suspected and accused of committing a crime, may change since the lists have been submitted to the court.

Thus, the amendments proposed by the draft law do not contain a comprehensive mechanism for verification of information about the candidates for jurors when the jury is being compiled.

\section{Compiling a preliminary list of candidates for jurors and sending summons}

After the selection of potential jurors is completed by the court staff member, a preliminary list is compiled. The list includes individuals who have the right to serve as jurors in accordance with the law. Citizens on the list are sent summons indicating the date of arrival at the court no later than 7 days before the trial starts. At the same time, the summons usually sets up the time of appearance in court one hour prior to the court session.

In the scientific literature this stage is characterized as one of the most difficult for the reason that the citizens do not often appear in court because they are not willing to conflict with their employer, do not understand the process and consequences of their jury service. Analysis of academic literature shows that the appearance of empaneled jurors in court by /summons comprises two to six percent (Kolokolov, 2015:3-9; Gurskaya, 2016:37-40; Venev, 2016:50—52).

Therefore, it seems very important to pay attention to legal education of the population including a trial by jury, explaining not only the goals and objectives of such a trial, but also the rights of citizens acting as jurors, as well as their protection.

In this regard, we consider it useful to refer to the experience of the Kingdom of Spain, where the secretariat of the court sends to candidate jurors notifications to fulfill the jury duty and attaches a brochure about the jury trial by mail (Jurishina, 2020:87-98). Such was the practice in the early years of the juries in post-Soviet Russia. We believe it is possible to borrow this useful experience by providing jurors with general information about the jury service, the rights and obligations of citizens involved in the administration of justice in a specially designed brochure. To reduce the cost of mailing the brochures, it is advisable to send them by e-mail (to those candidates who have-mail addresses). In the absence of such opportunity, the summons should include a link to the website (and/or QR code) where the brochure is posted; also, such information should be presented to the citizens at the court upon their arrival.

\footnotetext{
15 E. Korobka. Municipal Bodies will be Able to Get a Guaranteed Access to Information on Convictions of Candidates for Jurors. Advocacy Gazette June 29, 2020. Available at: https://www.advgazeta.ru/novosti/ munitsipalnye-organy-smogut-poluchit-garantirovannyy-dostup-k-svedeniyam-o-sudimosti-kandidatov-vprisyazhnie/ [Accessed $20^{\text {th }}$ October 2020].
} 
In addition, one of the negative trends complicating the organization of a jury trial is that often the citizens do not inform the court about the reasons for their failure to appear in court, which makes the work of the court more difficult. In this regard, it is necessary to raise the legal awareness of citizens, drawing their attention to the negative consequences of their non-appearance.

\section{The Use of Digital Technologies in Organizing Jury Trials: the US Experience}

The COVID-19 pandemic has introduced its own adjustments to the work of courts around the world. Meanwhile, a number of innovations can be successfully applied after the sanitary and epidemiological situation has stabilized. In this regard, the experience of the state of Alaska (USA) in compiling a jury during the pandemic is quite interesting. The Jury Service calls potential jurors to perform their duties by e-mail, thus eliminating the presence of a large number of people in waiting rooms. At the same time, a memo with the information about coronavirus infection symptoms, and an action algorithm in case the symptoms are identified is attached to the invitation.

Every citizen who has received juror summons can verify online if he/she is indeed called to court by the number indicated in the summons and the date of his/her birth at the official website of the court; they can also specify the time of appearance and contacts for communication with the Jury Service. Using this service helps to exclude cases of fraud and convince a citizen of the accuracy of the information received. Also, a citizen can use a free service designed to remind a candidate juror of the obligation to arrive at court at the due date and time. To do this, he/she needs to log in to the official website of the court, add his/her mobile phone number and agree to receive a reminding message.

The jury is compiled prior to the arrival of a potential juror in court. A staff member of the Jury Service will email the juror a questionnaire to determine if the candidate meets the formal requirements of the state law for jurors. Then the parties, using online video communication technologies, ask potential jurors questions to determine whether a citizen needs to come to the court for further participation in the selection ${ }^{16}$.

In case it is inconvenient for an individual to perform the juror's duties on the days scheduled, the candidate may ask to postpone the service to a later date within the next 10 months $^{17}$.

Thus, establishing the right of citizens to postpone the jury duty and sending summons via e-mail (with the consent of the citizen) or his/her personal account at the Unified Portal of State and Municipal Services, may optimize the process of jury compilation, making it more convenient both for the Russian citizens and court staff.

\footnotetext{
16 See: Jury Service Alaska Court System. Available at: http://www.courts.alaska.gov/jury/index.htm [Accessed 22 $2^{\text {nd }}$ October 2020].

${ }^{17}$ A similar rule applies on the territory of other states. For example, in the state of Massachusetts a possibility of a citizen to apply for a postponement of the day of service is also provided for. In other words, citizens can determine the most convenient days to participate in the trial as a juror in advance. This procedure is supported by the American lawyers, since it facilitates the compilation of a jury when considering other cases. See: (Astafiev, 2019).
} 


\section{Conclusion}

To summarize, we have worked out the key suggestions aimed at improving efficiency of managing the relations arising during a jury compilation.

It is proposed to use the database of the Unified Federal Information Register created in 2020 that contain current information about the population of the Russian, as opposed to the GAS Vybory, when compiling the general and reserve lists of jurors.

At the same time it is necessary to stipulate in the federal law the procedure for providing a secretary of the court or judge's assistant with the information about candidate jurors for verification of circumstances preventing an individual from participating in a criminal case as a juror as provided for by the Federal Law amending Article 326 of the Russian Criminal Procedure Code and Part 1 of Article 12 of the Federal Law On Police in terms of obliging the police to provide information on the presence (absence) of a criminal record and/or the fact of criminal prosecution at the request of the court staff member.

Provision should be made for a video recording of the process [screen broadcast] of a random selection of citizens from the general and reserve lists by the court staff member on a personal computer. The video file should be added to the criminal case file.

Also, it is necessary to consider the use of new forms of summoning potential jurors via e-mail and/or a citizen's personal account at the Unified Portal of State and Municipal Services.

It would be appropriate to stipulate the right of citizens to defer the duties of a candidate juror to a later date than it was originally intended, for example, within 12 months from the date of receipt of the first call to appear in court as a candidate for juror.

\section{References / Список литературы}

Avdeeva, E.V. \& Aksenov, A. N. (2019) Revocation of Sentences with the Participation of Jurors: Current Issues of the Criminal Procedure Regulation. Russian judge. (10), 13-18. (in Russian).

Авдеева Е.В., Аксенов А.Н. Отмена приговоров с участием присяжных заседателей: актуальные вопросы уголовно-процессуального регулирования // Российский судья. 2019. № 10. C. 13-18.

Astafiev, A.Yu. (2019) Where does a Jury Start? Russian Judge. (4), 40 - 43. (in Russian). Астафьев А.Ю. С чего начинается суд присяжных? // Российский судья. 2019. № 4. C. $40-43$.

Astafiev, A.Yu. (2018) Socio-Legal Foundations of the Implementation of Justice on Criminal Cases with the Participation of Jurors. Administrator of the Court. (1), 26-29. (in Russian).

Астафьев А.Ю. Социально-правовые основы осуществления правосудия по уголовным делам с участием присяжных заседателей // Администратор суда. 2018. № 1. C. $26-29$.

Dzhabrailov, M.A. (2012) Issues of Improving the Mechanism for Jury Compilation. Russian Investigator. (22), 41-45. (in Russian).

Джабраилов М.A. Проблемы совершенствования механизма формирования коллегии присяжных заседателей // Российский следователь. 2012. № 22. С. 41— 45. 
Gabov, A.V. \& Hromova, N.M. (2016) Jury Trial in Russia: A New Reform. Judge. (5), 4-11. (in Russian).

Габов А.В., Хромова Н.М. Суд присяжных в России: новая реформа // Судья. 2016. № 5. C. $4-11$.

Gurskaya, S.N. (2016) Trends of the Development of the Legal Institution of Jurisdiction of Criminal Cases to the Court with the Participation of Jurors in the Criminal Process of Russia. Russian Justice. (4), 37-40. (in Russian).

Гурская C.Н. Направления развития правового института подсудности уголовных дел суду с участием присяжных заседателей в уголовном процессе России // Российская юстиция. 2016. № 4. С. 37-40.

Jurishina, E.A. (2020) Jury Trial in Spain: Historical Retrospective, Prerequisites for Revival and Some Distinctive Features. Questions of Russian and International Law. 10(3A), 87-98. (in Russian).

Юришина Е.А. Суд присяжных в Испании: историческая ретроспектива, предпосылки возрождения и некоторые отличительные особенности // Вопросы российского и международного права. 2020. Т. 10. № 3А. С. 87-98.

Kolokolov, N.A. (2015) The Future of the Jury in Russia: The President of the Russian Federation - Asked, the Society Answered. Criminal Proceedings. (2), 3-9. (in Russian).

Колоколов Н.А. Будущее суда присяжных в России: Президенту РФ - спросил, общество ответило // Уголовное судопроизводство. 2015. № 2. С. $3-9$.

Lukin, V. P. (2004) Problems of Improving the Activity of the Jury in Modern Russia. Security of Eurasia. 4 (18), 229-243. (in Russian).

Лукин В.П. Проблемы совершенствования деятельности суда присяжных в современной России // Безопасность Евразии. 2004. № 4 (18). С. $229-243$.

Osipov, A.L. (2016) Issues of the Jury Compilation. Judge. (5), 29-32. (in Russian).

Осипов А.Л. Вопросы формирования коллегии присяжных заседателей // Судья. 2016. № 5. C. $29-32$.

Pashin, S.A. (2008) Procedural Problems of the Russian Courts with Jurors' Participation. Bulletin of the Jury Club. (1), 43-49. (in Russian).

Пашин С.A. Процессуальные проблемы российского суда с участием присяжных заседателей // Вестник клуба суда присяжных. 2008. № 1.С. 43-49.

Petruhin, I.L. (2009) The Acquittal and the Right for Rehabilitation: Monograph. Moscow, Prospect Publ. (in Russian).

Петрухин И.Л. Оправдательный приговор и право на реабилитацию: монография. М.: Проспект, 2009. 192 c.

Tarasov, V.N. (2016) Trends and Problems of the Development of the Institution of the Jury Trial in Russia. Judge. (5), 15-19. (in Russian).

Тарасов B.H. Тенденции и проблемы развития института суда присяжных в России // Судья. 2016. № 5. С. 15-19.

Tisen, O.N. (2008) On the Problem of the Need for Additional Verification of Information about Candidates for Jury. Administrator of the Court. (4), 7-9. (in Russian).

Тисен O.Н. К проблеме о необходимости дополнительной проверки сведений о кандидатах в присяжные заседатели // Администратор суда. 2008. № 4. С. 7—9.

Fadeeva, E.I. (2019) Problems of Ensuring the Legal Composition of the Jury When Considering Criminal Cases. Advocate Practice. (6), 46-49. (in Russian).

Фадеева Е.И. Проблемы обеспечения законного состава коллегии присяжных заседателей при рассмотрении уголовных дел // Адвокатская практика. 2019. № 6. С. 46-49.

Sheremetyev, I.I. (2019) The Use of Digital Technologies in the Consideration of Criminal Cases in Court: Reality and Prospects. Lex russica. (5), 117-131. (in Russian).

Шереметьев И.И. Использование цифровых технологий при рассмотрении уголовных дел в суде: реальность и перспективы // Lex russica. 2019. № 5. С. 117-131. 
Vedishhev, N.P. (2011) Compiling a Preliminary List of Jurors. Advocate. (1), 19-28. (in Russian). Ведищев Н.П. Составление предварительного списка присяжных заседателей // Адвокат. 2011. № 1. С. 19-28.

Venev, D.A. (2016) Jurisdiction of the Court with the Participation of Jurors in the Criminal Process of Russia - Issues and Prospects. Russian Justice. (10), 50-52. (in Russian).

Венев Д.А. Подсудность суда с участием присяжных заседателей в уголовном процессе России - вопросы и перспективы // Российская юстиция. 2016. № 10. С. 50 - 52.

Vladykina, T.A. (2018) Theoretical Model of Criminal Proceedings Considered by the Court with the Participation of a Jury. Dis. Doctor of Law. Ekaterinburg. (in Russian).

Владыкина T.A. Теоретическая модель производства по уголовным делам, рассматриваемым судом с участием присяжных заседателей: дисс. ... д-ра юрид. наук. Екатеринбург. 2018. 442 с.

\section{About the authors:}

Sergey A. Pashin - Honored lawyer of the Russian Federation, retired Federal judge, Candidate of Legal Sciences, Professor of the Department of Judicial Systems and Criminal law, National Research University Higher School of Economics (NRU HSE); 20 Myasnitskaya str., Moscow, 101000, Russian Federation

\section{ORCID ID: 0000-0003-3193-6496}

e-mail: os-spos@yandex.ru

Nikita V. Bushtets - Chief Specialist of the Center for Notary Research Foundation; postgraduate student of the Department of Judicial Systems and Criminal Law, National Research University Higher School of Economics (NRU HSE); 20 Myasnitskaya str., Moscow, 101000, Russian Federation

\section{ORCID ID: 0000-0002-7019-1389}

e-mail:n.bushtets@mail.ru

\section{Об авторах:}

Пашин Сергей Анатольевич - кандидат юридических наук, профессор Департамента систем судопроизводства и уголовного права факультета права НИУ «Высшая школа экономики», заслуженный юрист Российской Федерации, федеральный судья в отставке; 101000, Российская Федерация, г. Москва, Мясницкая ул., д. 20

\section{ORCID ID: 0000-0003-3193-6496}

e-mail: os-spos@yandex.ru

Буштец Никита Владимирович - аспирант Департамента систем судопроизводства и уголовного права факультета права НИУ «Высшая школа экономики», главный специалист Фонда «Центр нотариальных исследований»; 101000, Российская Федерация, г. Москва, Мясницкая ул., д. 20

ORCID ID: 0000-0002-7019-1389

e-mail: n.bushtets@mail.ru 